\title{
Chemical Analysis of Limestone of Bojhe, Halesi-Tuwachung Municipality, for Industrial Applications
}

\author{
Ram Bahadur Gharti', Dipak Kumar Hitan ${ }^{2}$, Manoj Kumar Prasad ${ }^{3}$, Prabin Shrestha ${ }^{3}$, Hari Bhakta Oli ${ }^{*}$ \\ ${ }^{1}$ Department of Mines and Geology, Ministry of Industry, Commerce and Supplies, Kathmandu, Nepal \\ ${ }^{2}$ Department of Customs, Ministry of Finance, Kathmandu, Nepal \\ ${ }^{3}$ Department of Chemistry, Amrit Campus, T.U., Kathmandu, Nepal \\ *Email: haribhakta69@gmail.com
}

(Received: 22 April, 2020, Received in revised form: 2 August, 2020, Accepted:10 August, 2020, Available online)

\section{Highlights}

- 143 limestone samples were collected from Halesi-Tuwachung, Khotang.

- Samples were subjected to a temperature of $1000{ }^{\circ} \mathrm{C}$ for an hour to determine LOI.

- Samples were subjected to acid to determine acid insoluble matter.

- Samples were analysed by titrimetric and AAS method to determine oxides.

- Collected limestone samples were found to meet industrial raw material specifications for cement industry

\begin{abstract}
Limestone is principal raw material for cement making industries. Chemical composition of limestone plays great role for making good quality cement. Production of good quality cement is of primary importance for the increment of the durability of infrastructure. Nepal is establishing large number of cement industries that uses limestone as raw materials and it is urgent to determine the quality of limestone. Quantitative Chemical analysis of one hundred forty three (143) limestone samples, collected by the channel sampling method, is carried out using gravimetric, titrimetric, and atomic absorption spectroscopic methods. The determined values of different parameters in percentages are as follows; loss on ignition (41.96385 \pm 0.670325$)$, acid insoluble

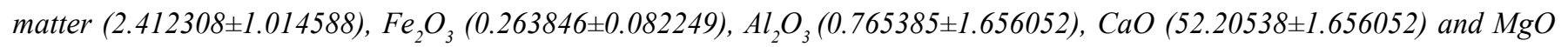
(3.018462 \pm 0.703886$)$. The results indicated that most of the limestone samples are found to meet industrial raw material specifications for some industries. They can be used in the cement, agriculture (liming of soil and fish ponds) and metallurgical purification processes in the steel industry. Collected limestone samples meet the raw material specification of some industries. So establishment of such industries from a chemical point of view is feasible.
\end{abstract}

\section{Graphical Abstract}

Key words: Limestone, Channel sampling, AAS, Industrial

*Corresponding author

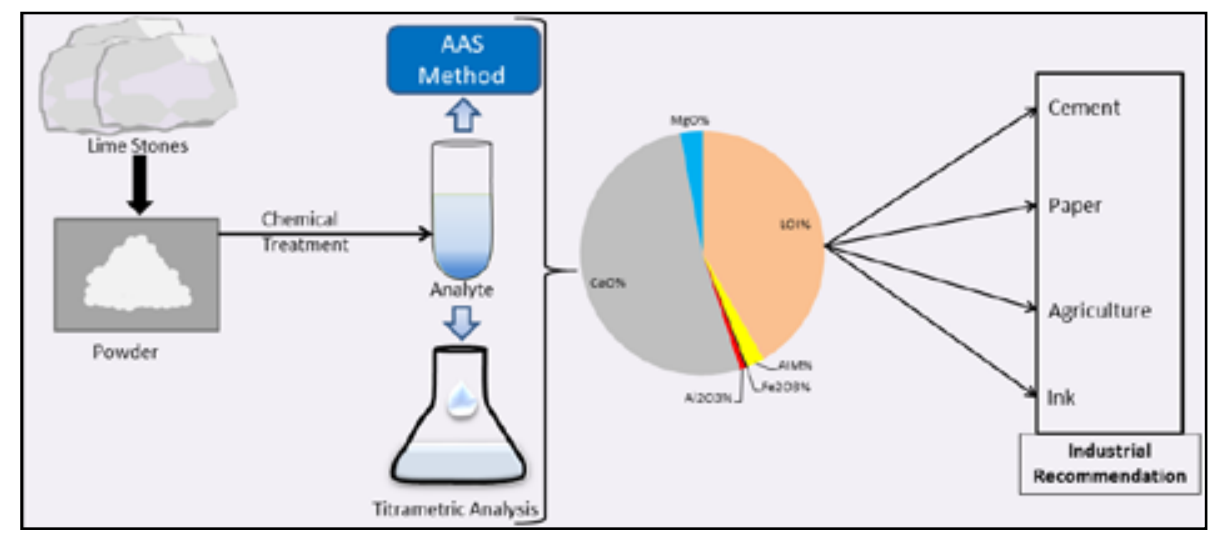




\section{Introduction}

Limestone is consists of primarily of calcium carbonate (at least $50 \%$ of $\mathrm{CaCO}_{3}$ ) in the form of mineral calcite. Limestone is also known as sedimentary rock as it is formed by sedimentation of mineral calcite, minerals and other non-carbonate impurities at suitable environment (Kiattikomol et al, 2000; Bouazza et al, 2016). Limestone is the key raw materials for the cement making industry where chemical properties are important. Portland cement is produced by the calcination of finely ground raw mixture of limestone and clay (Bouazza et al, 2016).

Cement industry is major player for the construction of infrastructures in the development of the country. For the great investment and establishment of cement industry, there are essential elements to be considered like; correct infrastructure selection for location of industry (Ozguner et al, 2014), sufficient reserves of raw materials and a typical sampling of the raw materials used to make Portland Cement (Shah et al, 2007), correct calculations for the feasible clinker mixtures and chemical study of the raw material (Khurshid et al, 2008; Aloui et al, 2008), and raw mix designing (Noor-ul-Amin et al, 2009).

Similarly, agricultural lime (calcium oxide) is added to soil to increase the $\mathrm{pH}$ of the soil. More than $\mathrm{pH} 5.5$ is suitable for the green leafy vegetable. Good quality of lime for agricultural industry must contain more than $50 \%$ of Calcium oxide (Biskup and Venskutonis, 2004 \& 2012).

Different countries may have same or different specifications of limestone for cement industries. But widely accepted practice for the constituent of cement production is $\mathrm{CaO}$ ( $45 \%$ min.), $\mathrm{MgO}$ (3\% max.) and desired impurities of $\mathrm{SiO}_{2}, \mathrm{Al}_{2} \mathrm{O}_{3}$ and $\mathrm{Fe}_{2} \mathrm{O}_{3}$. Similarly, the metallurgical industries and agricultural industries need limestone raw materials containing more than $50 \% \mathrm{CaO}$ (Harben, 1995).

There are more than 50 cement industries listed in the department of industry, Nepal (Department of Industry, 2019: NBSM, 2014: Pandey, 2019). Such industries are using limestone located in different part of Nepal as primary raw material. The composition of limestone plays great role for manufacture of good quality cement. Similarly, good quality of agricultural lime helps to increase the crop yield by increasing the $\mathrm{pH}$ of soil. Industries need good quality of limestone raw material for production of quality products. So, the aim of this research work is to assess the composition, ascertain the quality and assess their suitability with potentials for cement production, steel production and agricultural products production.

\section{Materials and Methods}

One hundred forty three (143) limestone samples were collected from Halesi-Tuwachung Municipality, Bojhe, Khotang District by channel sampling method. All samples were collected from 13 different channels, each channel containing eleven samples, were labeled from A to M. Each sample was mechanically converted into chips, pulverized into powder form by using grinding mill. A known weight of each sample was allowed to heat to a temperature of $1000{ }^{\circ} \mathrm{C}$ for an hour to determine loss on ignition. By this method, a rough proportion of the carbonate contents in the test samples can be obtained (Vogel, 1978).

For the determinations of the proportions of insoluble matter, pure silica and combined oxides gravimetric methods were used. The calcium and magnesium oxides content in the test samples were determined by titration method as described by Jeffery et al (1997). A known weight of the limestone samples was digested with 1:1 $\mathrm{HCl}$, followed by addition of 2 drops of conc. $\mathrm{HNO}_{3}$ for determination of acid insoluble matter (Jeffery et al, 1997: Oli \& Gharti, 2018). Atomic absorption spectrophotometer (Shimadzu, AA-7000, Japan) was used for the determination of Aluminium and Iron calculated in the form of oxide (Oli \& Gharti, 2018). The test sample solutions were subjected in the flame of AAS and absorbance of each sample was recorded. The absorbance of standard solutions of mineral/metal was used to compare with the recorded absorbance of respective test sample solutions, and the amount of metal in test samples was determined by the calibration curve method.

Loss on ignition of the samples was determined by IS1760(Part I):1991 method, acid insoluble matter was determined by IS1760(Part 2):1991 method. Similarly, percentage of $\mathrm{CaO}, \mathrm{MgO}$ and $\mathrm{Al}_{2} \mathrm{O}_{3}$ was determined by IS1760(Part 3):1991 method as reported by Oli et al (2018). Statistical analysis was the main method used to analyze the collected data (Pandey, 2015). Calculated values of each sample of each channel were statistically treated before tabulation and before presentation in diagram. Mean value and standard deviation of each parameter for each channel was calculated. 


\section{Results and Discussion}

Loss on ignition (LOI) gives the total volatile content, roughly the proportion of the carbonate in test samples but not enough to provide actual carbonate content. Here, the value obtained for LOI in every test sample is in the range (40-43\%) as in figure 1.

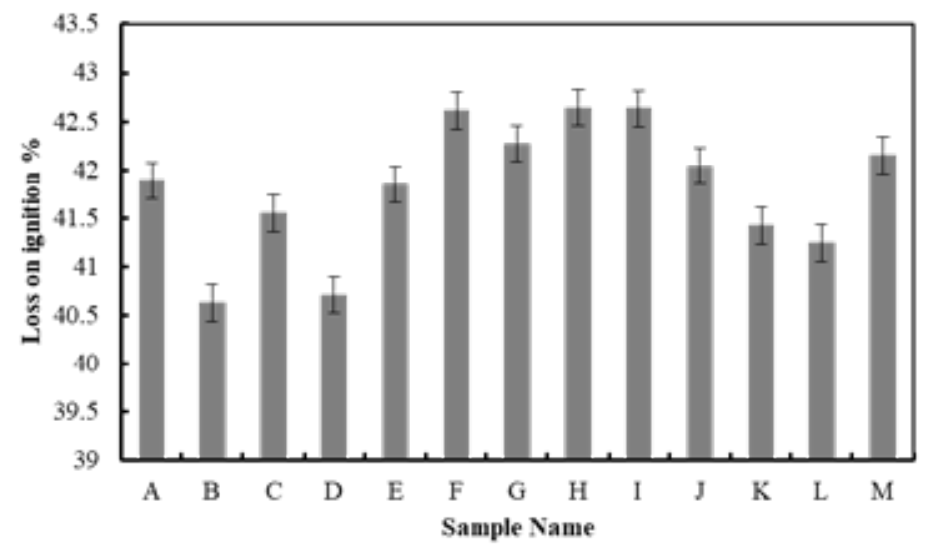

Fig 1: Average percentage of LOI value of limestone samples.

Acid insoluble matter was determined in all limestone samples and found below 3\% except samples from two channels A, $\mathrm{K}$ and $\mathrm{M}$ (Figure 2).This value of AIM in raw material is quite good. Insoluble residue is non-cementing material and affects in the compressive strength of cement. For better performance of cement, AIM should be less than $0.75 \%$ in commercial cement (Kiattikomol et al, 2000).

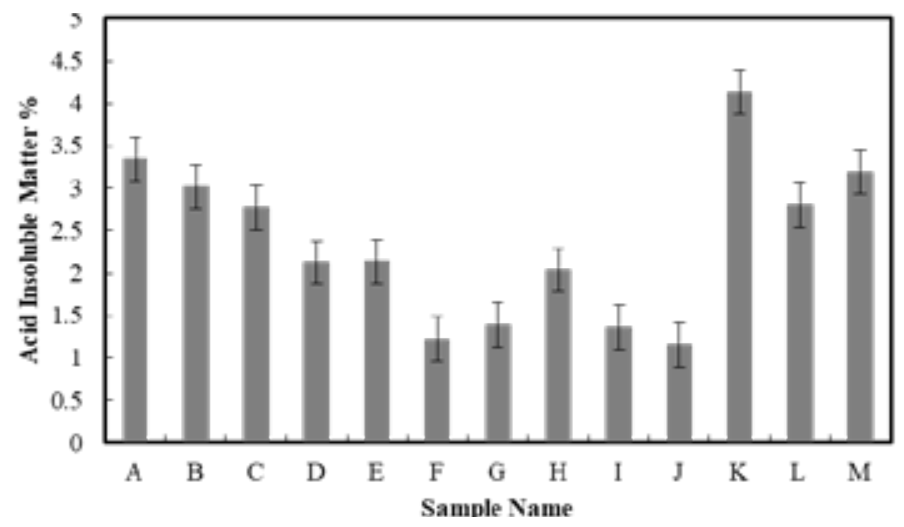

Fig 2: Average percentage of AIM value of limestone samples.

Calcium oxide is major portion of limestone. The amount of calcium oxide content in limestone samples is more than $50 \%$ except samples from channel A (Figure 3). The values obtained are in good agreement with the specifications for cement manufacturing, metallurgical application for steel industries and for liming of soil (Harben, 1995).

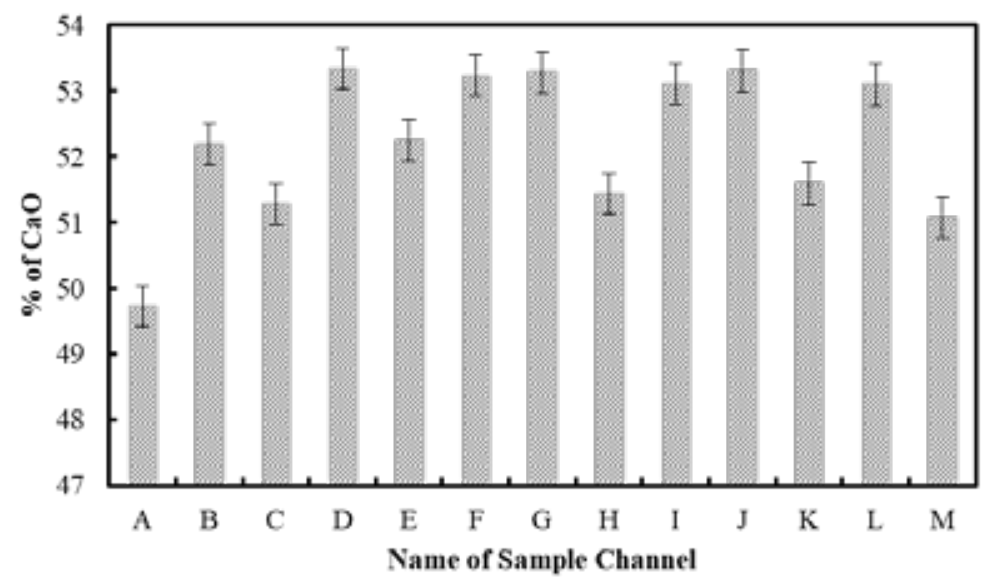

Fig 3: Average percentage of $\mathrm{CaO}$ value of limestone samples. 
Magnesium oxide contained in collected sample was determined. The average $\%$ of $\mathrm{MgO}$ contained in each limestone sample is found below 4.5\% (Figure 4). This is good criteria for cement production. The \% of MgO contained should be less than 5\% in raw materials and less than $3 \%$ in cement (Harben, 1995). In case of Nepal(Nepal Standard), the maximum permissible limit of $\mathrm{MgO}$ is $5 \%, 6 \%$ and $8 \%$ for Ordinary Portland Cement(OPC), Portland Pozzolona Cement(PPC) \&Portland Slag Cement(PSC) respectively (NBSM, 2014).

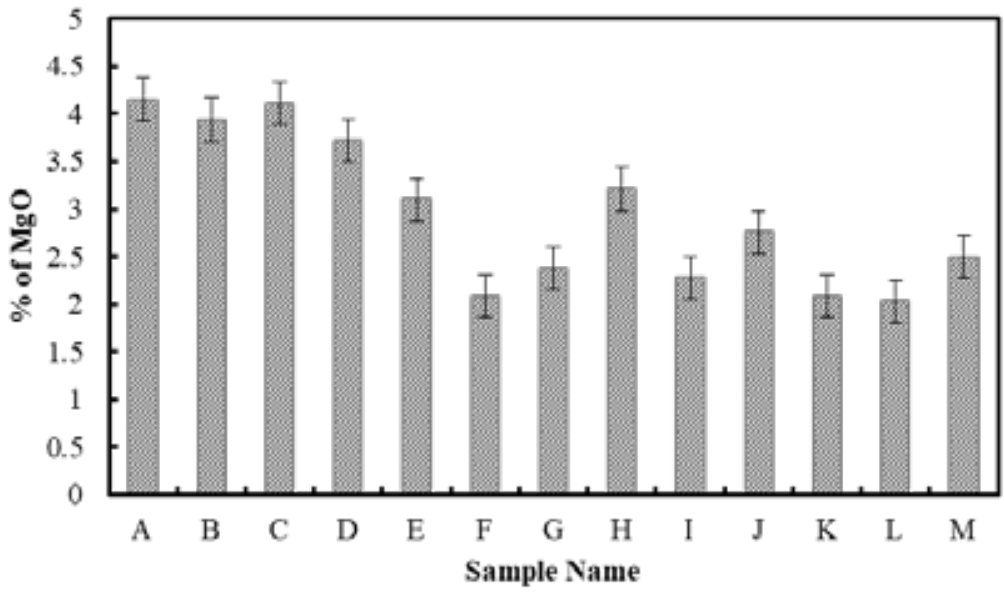

Fig 4: Average percentage of $\mathrm{MgO}$ value of limestone samples.

The percentage of $\mathrm{Al}_{2} \mathrm{O}_{3}$ and $\mathrm{Fe}_{2} \mathrm{O}_{3}$ in every sample was found less than $1.2 \%$ and $0.5 \%$ respectively (Figure $5 \& 6$ ). The less value of these oxides in raw materials is applicable for ink and pigment production (Ayuba et al, 2015). Fewer amounts contained of $\mathrm{Fe}_{2} \mathrm{O}_{3}$ and $\mathrm{Al}_{2} \mathrm{O}_{3}$ in the samples is also good agreement with specifications of cement and steel industries (Harben, 1995).

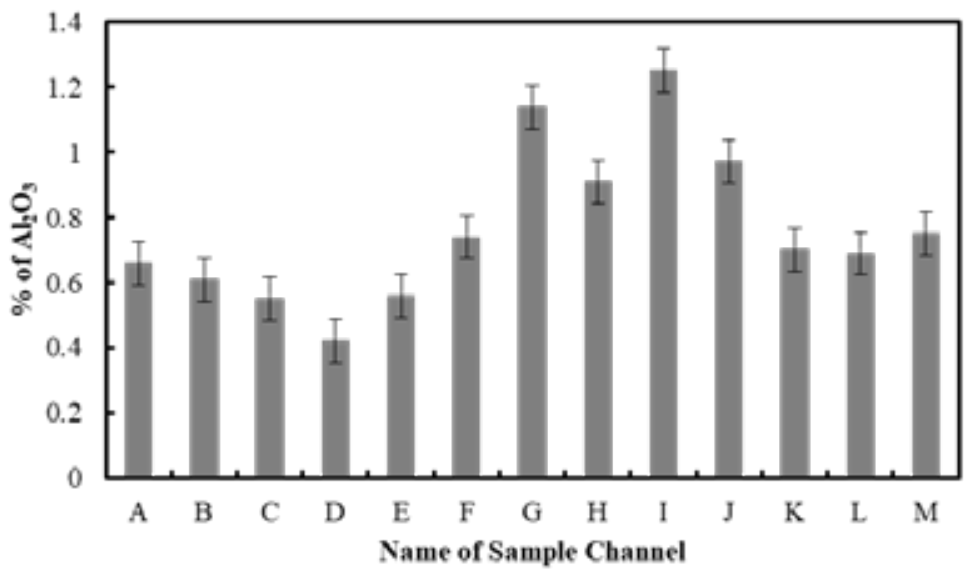

Fig 5: Average percentage of $\mathrm{Al}_{2} \mathrm{O}_{3}$ value of limestone samples

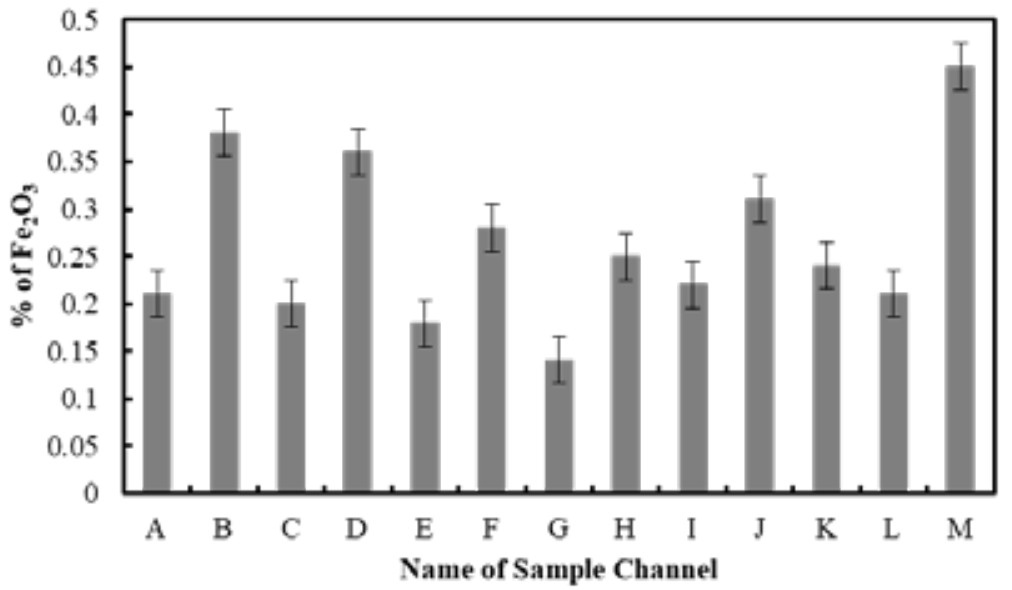

Fig 6: Average percentage of $\mathrm{Fe}_{2} \mathrm{O}_{3}$ value of limestone samples. 
Chemical composition of limestone is calculated in the form of different parameters like; loss on ignition, acid insoluble matter and oxides of iron, aluminium, calcium and magnesium. The obtained values are tabulated below (Table 1).

The principle raw material for the production of cement is limestone. Still there is no any hard and fast specification of limestone for cement industry is established but generally cement industries prefer limestone containing about $45 \% \mathrm{CaO}$. The impurities like $\mathrm{SiO}_{2}, \mathrm{Al}_{2} \mathrm{O}_{3}$ and $\mathrm{Fe}_{2} \mathrm{O}_{3}$ are desired. But the amount of $\mathrm{MgO}$ in limestone raw materials should not be more than 5\% (Harben, 1995: Kurt, 1981).

Table 1: Average measured value of different parameters of limestone raw materials

\begin{tabular}{|c|c|c|c|c|c|c|}
\hline $\begin{array}{c}\text { Name of Sample } \\
\text { Channel }\end{array}$ & $\begin{array}{c}\text { Loss on Igni- } \\
\text { tion LOI\% }\end{array}$ & $\begin{array}{c}\text { Acid Insoluble } \\
\text { Matter AIM\% }\end{array}$ & \% of $\mathrm{Fe}_{2} \mathrm{O}_{3}$ & \% of $\mathrm{Al}_{2} \mathrm{O}_{3}$ & $\%$ of CaO & $\%$ of MgO \\
\hline $\mathrm{A}$ & 41.89 & 3.34 & 0.21 & 0.66 & 49.73 & 4.15 \\
\hline $\mathrm{B}$ & 40.63 & 3.02 & 0.38 & 0.61 & 52.19 & 3.94 \\
\hline $\mathrm{C}$ & 41.55 & 2.77 & 0.2 & 0.55 & 51.28 & 4.11 \\
\hline $\mathrm{D}$ & 40.71 & 2.12 & 0.36 & 0.42 & 53.34 & 3.72 \\
\hline $\mathrm{E}$ & 41.85 & 2.13 & 0.18 & 0.56 & 52.25 & 3.1 \\
\hline $\mathrm{F}$ & 42.61 & 1.22 & 0.28 & 0.74 & 53.23 & 2.08 \\
\hline $\mathrm{G}$ & 42.27 & 1.39 & 0.14 & 1.14 & 53.28 & 2.38 \\
\hline $\mathrm{H}$ & 42.64 & 2.04 & 0.25 & 0.91 & 51.44 & 3.21 \\
\hline $\mathrm{I}$ & 42.63 & 1.36 & 0.22 & 1.25 & 53.11 & 2.28 \\
\hline $\mathrm{J}$ & 42.04 & 1.15 & 0.31 & 0.97 & 53.31 & 2.76 \\
\hline $\mathrm{K}$ & 41.42 & 4.13 & 0.24 & 0.7 & 51.6 & 2.08 \\
\hline $\mathrm{L}$ & 41.24 & 2.8 & 0.21 & 0.69 & 53.1 & 2.03 \\
\hline M & 42.15 & 3.19 & 0.45 & 0.75 & 51.07 & 2.5 \\
\hline Mean & 41.81769 & 2.358462 & 0.263846 & 0.765385 & 52.22538 & 2.949231 \\
\hline Standard Deviation & \pm 0.62881 & \pm 0.8659 & \pm 0.082249 & \pm 0.222313 & \pm 1.05401 & \pm 0.747438 \\
\hline
\end{tabular}

Measured values of our samples are in accordance with this specification (Table 1). So, from these raw materials, Portland cement can be manufactured. Metallurgical industries for steel manufacturing and agricultural industries for liming of soil require limestone raw materials containing $50 \%$ or more $\mathrm{CaO}$. Collected raw materials in this experiment also meet the criteria of these industries.

\section{Conclusions}

Various parameters of lime stones have been measured by using standard protocol. The determined values of those parameters are within the industrial specification. The results obtained by chemical analysis and also comparison with some industrial specifications, it is clear that these samples have potential for some industrial applications. These limestone samples meet the raw material specifications of cement, agriculture, ink as well as pigment industry. Similarly, these limestone samples meet the specification for metallurgical purification processes in the iron/steel industries.

Almost components in limestone samples have been determined/calculated but still some components (heavy metals, minerals, carbonate and arsenic) have to be measured for pharmaceutical applications. Chemically the limestone raw materials are good enough to establish a cement industry. These researchers recommend establishing the cement industry from the chemical point of view.

\section{Acknowledgements}

Authors are gratefully thankful to Department of Chemistry, Amrit Campus for laboratory support and Department of Mines and Geology for laboratory and financial support. 


\section{References}

Aloui, T., Ounis, A. and Chaabani, F. 2008. Maastritchian Limestones of Feriana Mountain used in White Cement Production (central West Tunisia). Journal of American Ceramic Society. 91(11):3704-3713.

Ayuba, A.M., Audu, A.A. and Chahul, H.F. 2015. Chemical Analysis of some limestone samples from the Middle Belt Zone, Nigeria and Their Possible Industrial Applications, ChemSearch Journal, 6(1):38-45.

Bouazza, N., Mrihi, El A. and Maate, A. 2016. Geochemical assessment of limestone for cement manufacturing. Procedia Technology 22:211-218.

Harben, P.W. 1995. The Industrial Minerals Handy Book, Second Edition, A Guide to Markets, Specifications and Prices, Ontario, pp. 36-43.

Industrial statistics 2018/2019. Department of Industry, Ministry of Industry, Commerce and Supplies, Kathmandu, Nepal.

Jeffery, G.H., Bassett, J., Mendham, J. and Denney, R.C. 1997. Vogel's Text book of quantitative Chemical Analysis, ${ }^{\text {th }}$ Edition, Longman Publisher Ltd. pp. 600-625.

Khurshid, A., Noor-ul-Amin, Tahir Shah M. 2008. Chemical study of limestone and clay for cement manufacturing in Darukhula Nizampur, Nowshera District, NWFP, Pakistan. Chinese Journal of Geochemistry. 27:242-248.

Kiattikomol, K., Jaturapitakkul, C. and Tangpagasit, J. 2000. Effect of insoluble residue on properties of Portland cement. Cement and Concrete Research. 30:1209-1214.

Kurt, I., Larry, P., Rod, O. and Paul, G. 1981. Fundamentals of Chemistry in the Laboratory, 2nd Edition, Minneapolis, Mc Graw Hill Books, Minnesota, U.S.A., pp. 85-96.

Nepal Bureau of Standard and Metrology, 2014. Scheme of Testing and Inspection for Certification of Portland Pozzolana Cement According to NS 385, http://nbsm.gov.np/uploads/files/STI_PPC.pdf

Noor-ul-Amin, Tahir, S. and Khurshid, A. 2009. Raw mix designing, clinkerization and manufacturing of high strength Portland cement from the Limestone and clay of Darukhula Nizampur, Nowshera Distrect, NWFP, Pakistan, Chinese Journal of Geochemistry, 28:279-283.

Oli, H.B. and Gharti, R.B. 2018. Compositional analysis of Magnesite and Talc found in Kharidhunga, Dolakha. Amrit Journal. 2:17-20

Ozguner, A.M. 2014. Prospection of Portland cement raw material: A case study in the Marmara region of Turkey. Journal of African Earth Science. 97:230-243.

Pandey, B.R. 2019. An easy approach to Applied Chemistry, $4^{\text {th }}$ Edition, Heritage Publisher and Distributers Pvt. Ltd. Kathmandu, Nepal.

Pandey, B.R., 2015. An easy approach to Analytical Chemistry, $1^{\text {st }}$ edition, Heritage Publisher and Distributers Pvt. Ltd., Kathmandu, Nepal.

Shah, M.T., Fayez, A. and Ali, L. 2007. Chemical study of the raw material in Gandghar Range, District Haripur, NWFP, for Portland Cement manufacturing. Journal of Chemical Society of Pakistan. 29(2):103-109.

Stahl-Biskup, E. and Venskutonis, R.P., 2004. Handbook of Herbs and Spices, First edition, Woodhead Publishing, 2.

Stahl-Biskup, E. and Venskutonis, R.P., 2012. Handbook of Herbs and Spices, Second edition, Woodhead Publishing, 1.

Vogel, A.I. 1987. A textbook of qualitative Inorganic Analysis including Instrumental Analysis, $4^{\text {th }}$ Edition, Longman Group Limited, London. pp. 420-465. 